\title{
Article/Artigo
}

\section{Comparative biology of the two sister species of Triatominae (Hemiptera: Reduviidae)}

\author{
Biologia comparativa de duas espécies irmãs de Triatominae (Hemiptera: Reduviidae)
}

\author{
Ana Laura Carbajal de la Fuente ${ }^{1,2}$, Vanda Cunha ${ }^{3}$, Nathanielly Rocha ${ }^{1}$, Catarina Macedo Lopes ${ }^{1}$ and \\ François Noireau ${ }^{4}$
}

\begin{abstract}
Introduction: Triatoma pseudomaculata and T. wygodzinskyi (Hemiptera: Reduviidae: Triatominae) are two Brazilian vectors of Chagas disease. The first is an arboricolous species in sylvatic environment and considered a vector of T. cruzi in peridomestic structures; the second, a rupicolous species in the wild environment of no epidemiological importance. In order to test the assumption that sister species share biological traits, comparative studies of their development cycle and blood ingestion were conducted. Methods: Eggs laid by five field females of each species were randomly selected. The nymphs were observed daily and fed on mice weekly. The time required to pass through the different stages to adulthood was recorded in days. The triatomines were weighed individually before and after feeding. The mortality rate according to each nymphal stage was calculated. Results and conclusions: Analysis of the results shows that they display only minor biological differences even though they exhibit a distinct ecology. This suggests that the biological traits are important criteria to determine the relationship between species.
\end{abstract}

Key-words: Triatoma wygodzinskyi. Triatoma pseudomaculata. life cycle. feeding behavior.

\section{RESUMO}

Introdução: Triatoma pseudomaculata e T.wygodzinskyi (Hemiptera: Reduviidae: Triatominae) são dois vetores Brasileiros da doença de Chagas. A primeira é uma espécie arborícola em ambiente silvestre e considerada vetor do T. cruzi em estruturas peridomesticas. A segunda é rupícola em ambientes silvestres e sem importância epidemiológica. Com o objetivo de testar a hipótese que espécies irmãs compartilham características semelhantes, realizamos um estudo comparativo do ciclo biológico e ingesta alimentar. Métodos: Ovos pertencentes a cinco fêmeas de cada espécie provenientes do campo foram selecionados aleatoriamente. As ninfas foram observadas diariamente e alimentadas com camundongos semanalmente. O tempo requerido para passar até o estágio adulto foi registrado em dias. Os triatomíneos foram pesados individualmente antes e depois da alimentação. A mortalidade de cada estágio foi calculada. Resultados e conclusões: Analise dos resultados mostram que eles exibem pequenas diferencias biológicas apesar de apresentarem diferenças marcantes quanto a sua ecologia. Isso sugere que as características biológicos são critérios importantes para determinar a relação entre as espécies.

Palavras-chaves: Triatoma wygodzinskyi. Triatoma pseudomaculata. Ciclo de Vida. Hábito alimentar.

1. Laboratory, Leishmaniasis Transmitters, Medical and Forensic Entomology. Oswaldo Cruz Institute, Oswaldo Cruz Foundation, Rio de Janeiro, RJ, Brazil. 2. Laboratory of Triatominae and Epidemiology of the Chagas Disease. Rene Rachou Institute. Oswaldo Cruz Foundation, Belo Horizonte, MG, Brazil. 3. National and International Reference Laboratory in Taxonomy of Triatominae (LNIRTT). Oswaldo Cruz Institute, Oswaldo Cruz Foundation, Rio de Janeiro, RJ, Brazil. 4. Institut de Recherche pour le Développement (IRD), Montpellier, France.

Address to: Dra. Ana Laura Carbajal de la Fuente: Lab. Transm. Leishmaniose/Setor Entomologia Médica e Forense/FIOCRUZ. Av. Brasil 4365, 21045-900 Rio de Janeiro, RJ. Brazil.

e-mail: carbajal@ioc.fiocruz.br

Tel: 5521 2598-4320/22, Fax: $55212573-4468$

Received in 29/10/2009

Accepted in 19/01/2010

\section{INTRODUCTION}

Autochthonous species of Triatominae originally restricted to the wild environment are increasingly reported invading houses and peridomestic structures where they may act as vectors of Trypanosoma cruzi (Chagas, 1909), the agent of Chagas disease. Among these, Triatoma pseudomaculata (Corrêa \& Espínola, 1964), an arboricolous species in sylvatic environment, is considered a vector of $T$. cruzi in peridomestic structures. Nevertheless, it does not display significant ability for colonizing human dwelling, as verified by the scarcity of domestic colonies notified indoors ${ }^{1,2,3}$. Recently, one case of T. cruzi transmission by T.pseudomaculata to a woman was reported in Ceará State ${ }^{4}$. Therefore, the role of this species as an effective vector needs to be accurately investigated. A second autochthonous species is Triatoma wygodzinskyi Lent, 1951 (morphologically very similar to T. pseudomaculata). This rupicolous species was described among a small number of specimens collected in southern Minas Gerais State ${ }^{5,6}$. Recently, genetic and morphometric comparisons suggest that both species belong to the same evolutionary lineage; consequently, they should be classified together in the same group ${ }^{7,8}$.

The development cycle of triatomines is related to the species and environmental conditions and is deeply influenced by the accessibility of adequate blood sources 9 . The hypothesis of this work is that sister species, such as T. pseudomaculata and T. wygodzinskyi, share biological traits. In order to test this assumption, comparative studies of the development cycle and blood ingestion of both species were conducted under the same laboratory conditions. 


\section{METHODS}

\section{Sample origin}

T. pseudomaculata specimens were collected from peridomestic structures in the rural area of Curaçá $\left(9^{\circ} 28^{\prime}\right.$ S, 39 $44^{\prime}$ W), Bahía State, while T. wygodzinskyi was captured in cracks between rocks near Vargem Grande do Sul, São Paulo State ( $21^{\circ} 79^{\prime}$ S, $\left.46^{\circ} 84^{\prime} \mathrm{W}\right)$. Once captured, the specimens were kept in the laboratory under a natural light/dark regime, at a temperature of $28 \pm 2^{\circ} \mathrm{C}$, and $70 \pm 5 \%$ relative humidity.

\section{Development cycle}

Eggs laid by five field females of each species were randomly selected and individually placed in plastic containers $(12 \mathrm{~cm}$ high and $3 \mathrm{~cm}$ diameter), with filter paper inside to provide the developing insects with access to the food source. Each container was numbered and examined daily until egg hatching. The nymphs were observed daily and fed on mice weekly (Protocol CEUA: P0100-01) and the time required to pass through the different stages to adulthood recorded in days (d). The development times (total and by stage) were expressed in median values.

\section{Blood ingestion}

Throughout the different development stages, the triatomines were weighed individually on an analytical balance (DAHUS ${ }^{*}$ ) before and after feeding and the number of grams of blood ingested (mg) were calculated.

\section{Mortality}

The mortality rate according to each nymphal stage was calculated.

\section{Statistical methods}

For data interpretation concerning the development cycle and blood meal ingestion, normality and homogeneity of variances were assessed using the Levene and Bartlett tests, respectively. The median variables were analyzed using the Mann-Whitney test. For statistical tests, we used JMP v.6.0.0 (SAS Institute Inc., 2005). For the Chi square test on mortality range, we used GraphPad InStat v.3.05 (GraphPad Software, San Diego, CA, USA).

\section{RESULTS}

\section{Development cycle}

The total life cycle was slightly longer in T. pseudomaculata than T. wygodzinskyi (232 and 205 days, respectively, $p=0.0014$ ). Nevertheless, interspecies differences were only observed for egg and N5 duration, all the other stages showed similar durations (Table 1). Moreover, the differences were exclusively observed among female nymphs (data not shown).

\section{Blood ingestion}

T. pseudomaculata and T. wygodzinskyi needed a similar number of feeding periods ( 10 and 11 , respectively) to reach the adult stage. No significant difference was observed in the number of blood meals between both species (Table 2); however, the fourth and fifth nymphal instars of T. pseudomaculata ingested more blood than the corresponding stages in T. wygodzinskyi (Table 3).

\section{Mortality}

The mortality rates for each nymphal instar are shown in Table 4. Starting with 74 nymphs of T. wygodzinskyi, only 31 reached
TABLE I - Time of development (in days) according to the stage in T. wygodzinskyi and T. pseudomaculata.

\begin{tabular}{|c|c|c|c|c|c|c|c|}
\hline \multirow[b]{2}{*}{ Stage } & \multicolumn{3}{|c|}{ T. wygodzinskyi } & \multicolumn{3}{|c|}{ T. pseudomaculata } & \multirow[b]{2}{*}{$p$ value } \\
\hline & $\mathrm{N}$ & Median & $\begin{array}{l}\text { Quantiles } \\
(25-75 \%)\end{array}$ & $\mathrm{N}$ & Median & $\begin{array}{l}\text { Quantiles } \\
(25-75 \%)\end{array}$ & \\
\hline Egg & 74 & 19 & $18-23$ & 48 & 21 & $20-24$ & $0.0043^{*}$ \\
\hline N1 & 55 & 29 & $21-46$ & 41 & 34 & $26-46$ & N.S. \\
\hline N2 & 51 & 27 & $19-35$ & 31 & 23 & $16-37$ & N.S. \\
\hline N3 & 46 & 28 & $22-40$ & 26 & 29 & $24-34$ & N.S. \\
\hline N4 & 38 & 41 & $32-49$ & 25 & 35 & $27-48$ & N.S \\
\hline N5 & 31 & 68 & $55-82$ & 21 & 97 & $76-128$ & $0.0004^{*}$ \\
\hline Total & 31 & 205 & $189-230$ & 21 & 232 & $215-260$ & $0.0014^{*}$ \\
\hline
\end{tabular}

$\mathrm{N}$ (number of specimens), N1 ( $1^{\text {st }}$ nymphal instar), N2 ( $2^{\text {nd }}$ nymphal instar), N3 ( $3^{\text {rd }}$ nymphal instar $), N 4$ ( $4^{\text {th }}$ nymphal instar $)$, N5 ( $5^{\text {th }}$ nymphal instar $){ }^{*}$ Significant difference by the Mann-Whitney test. N.S. = not significant.

TABLE 2 - Number of blood meals according to the nymphal stage in T. wygodzinskyi and T.pseudomaculata.

\begin{tabular}{|c|c|c|c|c|c|}
\hline \multirow[b]{2}{*}{ Stage } & \multicolumn{2}{|c|}{ T. wygodzinskyi } & \multicolumn{2}{|c|}{ T. pseudomaculata } & \multirow[b]{2}{*}{$p$ value } \\
\hline & Median & $\begin{array}{l}\text { Quantiles } \\
(25-75 \%)\end{array}$ & Median & $\begin{array}{l}\text { Quantiles } \\
(25-75 \%)\end{array}$ & \\
\hline N1 & 2 & $2-3$ & 2 & $1-3$ & N.S. \\
\hline $\mathrm{N} 2$ & 2 & $1-2$ & 2 & $1-2.5$ & N.S. \\
\hline N3 & 2 & $1-2$ & 2 & $1-2$ & N.S. \\
\hline N4 & 2 & $2-2.5$ & 2 & $1-2$ & N.S. \\
\hline N5 & 3 & $2-4$ & 4 & $2-5$ & N.S. \\
\hline Total & 10 & $9-12$ & 11 & $9-13$ & N.S. \\
\hline
\end{tabular}

N1 ( $1^{\text {st }}$ nymphal instar), N2 ( $2^{\text {nd }}$ nymphal instar $), \mathrm{N} 3$ ( $3^{\text {rd }}$ nymphal instar $), \mathrm{N} 4$ ( $^{\text {th }}$ nymphal instar), N5 ( ${ }^{\text {th }}$ nymphal instar). ${ }^{*}$ Significant difference by the Mann-Whitney test. N.S. = not significant.

TABLE 3 - Blood meal ingested (in mg) according to nymphal stage in T. wygodzinskyi and T. pseudomaculata.

\begin{tabular}{|c|c|c|c|c|c|c|c|}
\hline \multirow[b]{2}{*}{ Stage } & \multicolumn{3}{|c|}{ T. wygodzinskyi } & \multicolumn{3}{|c|}{ T. pseudomaculata } & \multirow[b]{2}{*}{$p$ value } \\
\hline & $\mathrm{N}$ & Median & $\begin{array}{l}\text { Quantiles } \\
(25-75 \%)\end{array}$ & $\mathrm{N}$ & Median & $\begin{array}{l}\text { Quantiles } \\
(25-75 \%)\end{array}$ & \\
\hline $\mathrm{N} 1$ & 55 & 5.4 & $3.7-6.4$ & 41 & 4.3 & $3.2-5.9$ & N.S. \\
\hline $\mathrm{N} 2$ & 51 & 12.0 & $8.9-14.1$ & 33 & 11.4 & $7.6-15.2$ & N.S. \\
\hline N3 & 46 & 33.0 & $5.2-39.4$ & 26 & 33.0 & $25.9-40.8$ & N.S. \\
\hline N4 & 38 & 88.0 & $75.0-106.9$ & 25 & 100.4 & $93.5-111.0$ & $0.0413^{*}$ \\
\hline N5 & 31 & 282.6 & $228.2-336.6$ & 21 & 369.2 & $288.1-450.6$ & $0.0009^{*}$ \\
\hline Total & & 430.9 & $63.0-336.6$ & & 511.8 & $452.3-450.6$ & $0.0010^{*}$ \\
\hline
\end{tabular}

N1 ( $1^{\text {st }}$ nymphal instar $), \mathrm{N} 2$ ( $2^{\text {nd }}$ nymphal instar $), \mathrm{N} 3$ ( $3^{\text {rd }}$ nymphal instar $), \mathrm{N} 4$ ( $^{\text {th }}$ nymphal instar $)$, N5 ( $5^{\text {th }}$ nymphal instar). ${ }^{*}$ Significant difference by the Mann-Whitney test. N.S. = not significant.

TABLE 4 - Mortality rate according to nymphal stage in T. wygodzinskyi and T. pseudomaculata

\begin{tabular}{|c|c|c|c|c|c|c|c|c|c|}
\hline \multirow[b]{2}{*}{ Stage } & \multicolumn{4}{|c|}{ T. wygodzinskyi } & \multicolumn{4}{|c|}{ T. pseudomaculata } & \multirow[b]{2}{*}{$p$ value ${ }^{*}$} \\
\hline & $\overline{\mathrm{N}}$ & $\mathrm{n}$ & $\begin{array}{c}\text { Mortality } \\
\%\end{array}$ & $\begin{array}{l}\text { Cumulative } \\
\text { mortality \% }\end{array}$ & $\mathrm{N}$ & $\mathrm{n}$ & $\begin{array}{c}\text { Mortality } \\
\%\end{array}$ & $\begin{array}{l}\text { Cumulative } \\
\text { mortality\% }\end{array}$ & \\
\hline N1 & 74 & 55 & 25.7 & 25.7 & 48 & 41 & 14.6 & 14.6 & N.S. \\
\hline $\mathrm{N} 2$ & 55 & 51 & 7.3 & 31.1 & 41 & 31 & 24.4 & 35.4 & N.S. \\
\hline N3 & 51 & 46 & 9.8 & 37.8 & 31 & 26 & 16.1 & 45.8 & N.S. \\
\hline N4 & 46 & 38 & 17.4 & 48.7 & 26 & 25 & 3.9 & 47.9 & N.S. \\
\hline N5 & 38 & 31 & 18.4 & 58.1 & 25 & 21 & 16.0 & 56.3 & N.S. \\
\hline
\end{tabular}

N1 ( $1^{\text {st }}$ nymphal instar), N2 ( $2^{\text {nd }}$ nymphal instar), N3 ( $3^{\text {rd }}$ nymphal instar), N4 (4 $4^{\text {th }}$ nymphal instar), N5 ( $5^{\text {th }}$ nymphal instar)

$\mathrm{N}=$ Initial number, $\mathrm{n}=$ number of nymphs molting for the following stage. N.S. = not significant for the Chi square test.

${ }^{*}$ Chi-square test. 
the adult stage (global mortality rate of 58.1\%); a similar rate was determined for T. pseudomaculata (56.3\%). Mortality for each stage varied from 7.3 to $25.7 \%$ for T. wygodzinskyi and from 3.9 to $24.4 \%$ for T. pseudomaculata, the highest mortality rate was registered in N1 (25.67\%) for the former species and in N2 (24.4\%) for the latter. The interspecies comparison for each stage did not reveal any significant difference between the two species.

\section{DISCUSSION}

Several papers involve studies related to the biology of T. pseudomaculata, a triatomine species with an epidemiological role ${ }^{10,11,12,13,14}$. In contrast, no readily available information exists concerning the biology of T. wygodzinskyi, which is an exclusively sylvatic vector. In fact, the study conducted by Juarez $(1970)^{15}$ on the biological cycle of T. arthurneivai actually involves misidentified populations that are currently known as T. wygodzinskyi ${ }^{7,16}$.

In most cases, the disparities between the conditions maintained in individual insectaries, the methodologies and statistical analyses complicate the comparison of different studies relating to the same species $^{11}$. For example, the egg to adult life cycle showed an average duration of 255 days in this work, whereas it varied from 212 to 349 days according to other authors ${ }^{11,14}$. The differences observed are partly due to the influence of the blood meal source ${ }^{13}$.

The comparison of biological traits of two species under the same laboratory conditions is more informative. In the present study, the study began with eggs laid by field-collected females in order to limit the endogamy that occurs after a few generations in the laboratory. Concerning the life cycle, the differences observed between the two species are minor and limited to the development time of the egg and N5 stage in female insects. Regarding the blood meal parameters, the number of feeding periods showed no significant differences between the two species. Only the late nymphal instars of T. pseudomaculata ingest more blood than T. wygodzinskyi. This factor is epidemiologically important and suggests an increased risk of T. cruzi transmission in T. pseudomaculata. Finally, the interspecies comparison of the mortality rate showed no significant difference.

For a long time, T. maculata and T. pseudomaculata were considered closely related species ${ }^{17,18,19}$. Recently, this hypothesis was undermined by genetic and morphological studies ${ }^{7,8,20}$. When comparing the life cycles between these two species, it is clear that the life cycle of T. maculata is shorter than that of T. pseudomaculata. According to different authors, the N1-adult life cycle does not exceed 144 days for T. maculata, a much shorter duration than that observed for T. pseudomaculata (Table 5). The coherence of our results with the genetic and morphological studies suggests that

TABLE 5-Comparison between T. maculata and T. pseudomaculata life cycles according to the feeding source.

\begin{tabular}{|c|c|c|c|}
\hline Species & $\begin{array}{l}\text { Blood } \\
\text { source }\end{array}$ & $\begin{array}{c}\text { N1-adult life cycle in } \\
\text { days (average) }\end{array}$ & References \\
\hline \multirow{3}{*}{ Triatoma maculata } & bird & 144 & Espínola et al. (1981) ${ }^{21}$ \\
\hline & bird & Felicia & iangeli \& Rabinovich $(1985)^{22}$ \\
\hline & mouse & Luitg & itgards-Moura et al. $(2006)^{23}$ \\
\hline \multirow{3}{*}{ Triatoma pseudomaculata } & bird & 331 & Gonçalves et al. $(1997)^{11}$ \\
\hline & mouse & 233 & Guarneri et al. (2000) ${ }^{13}$ \\
\hline & mouse & 233 & This paper \\
\hline
\end{tabular}

biological traits are important criteria to determine the relationship between species. Regarding T. pseudomaculata and T. wygodzinskyi, sister species derived from a common ancestor, they have maintained similar biological traits even though they show a different ecology; the former is arboricolous and the latter is rupicolous.

\section{ACKNOWLEDGMENTS}

Specials thanks to L. Silva and C. Godoy for their technical assistance. To J.M.S. Barata, R. Hoffmman and P. Araújo, for their invaluable help in the work field.

\section{CONFLICT OF INTEREST}

The authors declare that there is no conflict of interest.

\section{FINANCIAL SUPPORT}

This study received financial support from Fundação Oswaldo Cruz, Coordenação de Aperfeiçoamento de Pessoal de Nível Superior - CAPES - (Brazil) and Institut de Recherche pour le Développement - IRD - (France). A.L.C.F. was supported by CAPES-I EL Nacional, Brazil.

\section{REFERENCES}

1. Souza LC, Frota FCC, Souza JA, Lima JWO. Descrição de um foco urbano de Triatoma pseudomaculata (Hemiptera: Reduviidae: Triatominae), na cidade de Sobral, norte do Ceará. Resultados preliminares. Rev Soc Bras Med Trop 1999; 32: 84-85.

2. Assis GF, Azeredo BV, Carbajal de la Fuente AL, Diotaiuti L, De Lana M. Domiciliation of Triatoma pseudomaculata Corrêa \& Espínola, 1964 in the Jequitinhonha Valley, State of Minas Gerais. Rev Soc Bras Med Trop 2007; 40: 391-396.

3. Carbajal de la Fuente AL, Dias-Lima A, Lopes CM, Emperaire L, Walter A Ferreira A, et al. Triatoma pseudomaculata and Triatoma juazeirensis (Hemiptera: Reduviidae): behavioural plasticity related to habitat selection in different environments. J Med Entomol 2008a; 45: 14-19.

4. Diotaiuti L. Transmissão do Trypanosoma cruzi por espécies secundárias. 25a Reunião de Pesquisa Aplicada em Doença de Chagas e 13a Reunião de Pesquisa Aplicada em Leishmaniose, Uberaba, 20 a 24/10/2009.

5. Lent H, Wygodzinsky P. Revision of the Triatominae (Hemiptera, Reduviidae), and their significance as vectors of Chagas disease. Bul Am Mus Nat Hist 1979; 163: $127-520$.

6. Carcavallo RU, Galindez Girón I, Jurberg J, Galvão C, Lent H. Pictorial keys for tribes, genera and species for the subfamily Triatominae. In RU Carcavallo, I Galindez Girón, J Jurberg, H Lent, Atlas of Chagas disease vectors in the Americas, Fiocruz, Rio de Janeiro, Brazil; 1999. p. 107-244.

7. Santos SM, Lopes CM, Dujardin JP, Panzera F, Pérez R, Carbajal de la Fuente AL, et al. Evolutionary relationships based on genetic and phenetic characters between Triatoma maculata, Triatoma pseudomaculata and morphologically related species (Reduviidae: Triatominae). Inf Gen Evol 2007; 7: 469-475

8. Carbajal de la Fuente AL, Noireau F, Catalá S. Inferences about antennal phenotype: the "maculata complex" (Hemiptera: Reduviidae) is valid? Acta Trop 2008b; 106: 16-21.

9. Schofield CJ. Triatominae: biology and control. Eurocommunica Publications, West Sussex, UK; 1994. p. 1-80.

10. Perlowagora-Szumlewics A. Laboratory colonies of Triatominae, biology and population dynamics. In PAHO Scient Publ, American Trypanosomiasis Research; 1976. p. 63-82. 
11. Gonçalves TCM, Cunha V,OliveiraE,JurbergJ.Alguns aspectos da biologia de Triatoma pseudomaculata Corrêa \& Espínola, 1964, em condições de laboratório (Hemiptera: Reduviidae: Triatominae). Mem Inst Oswaldo Cruz 1997; 92: 275-280.

12. Canale D, Jurberg J, Carcavallo R, Galvão C, Galindez-Girón I, Mena Segura C, et al. Bionomia de algumas espécies. In RU Carcavallo, I Galindez Girón, J Jurberg, H Lent, Atlas of Chagas disease vectors in the Americas, FIOCRUZ, Rio de Janeiro, Brazil; 1999. p. 349-890.

13. Guarneri AA, Pereira MH, Diotaiuti L. Influence of the blood meal source on the development of Triatoma infestans, Triatoma brasiliensis, Triatoma sordida, and Triatoma pseudomaculata (Heteroptera, Reduviidae). J Med Entomol 2000; 37: 373-379.

14. Soares RPP, Evangelista LG, Soares Laranja L, Diotaiuti L. Population dynamics and feeding behavior of Triatoma brasiliensis and Triatoma pseudomaculata, main vectors of Chagas disease in Northeastern Brazil. Mem Inst Oswaldo Cruz 2000; 95: 151155 .

15. Juarez E. Observações sobre o ciclo evolutivo de Triatoma arthurneivai em condições de laboratório. Rev Saúde Publ 1970; 4: 13-18.

16. Carbajal de la Fuente AL. Eco-genética comparativa das espécies afins Triatoma pseudomaculata Côrrea \& Espínola, $1964 \mathrm{e}$ T. wygodzinskyi Lent, 1951 (Hemiptera: Triatominae), $\mathrm{PhD}$ Thesis, Instituto Oswaldo Cruz, Rio de Janeiro, Brasil; 2007. p.1- 218.

17. Schofield CJ. Biosystematics of the Triatominae. In: MW Service Biosystematics of Haematophagous Insects, Systematics Association, Clarendon Press, Oxford; 1988. p. 284-312.

18. Carcavallo RU, Jurberg J, Lent H, Noireau F, Galvão C. Phylogeny of the Triatominae (Hemiptera: Reduviidae) Proposals for taxonomic arrangements. Entomol Vect 2000; 7: 1-99.

19. Dujardin JP, Schofield CJ, Panzera F. In: Les vecteurs de la maladie de Chagas. Recherches taxonomiques, biologiques et génétiques. Académie Royale des Sciences d'Outre-Mer, Bruxelles, Classe des Sciences Naturelles et Médicales, NS; 2000. p.1-162.

20. Hypša V, Tietz DF, Zrzavy J, Rego ROM, Galvão C, Jurberg J. Phylogeny and biogeography of Triatominae (Hemiptera: Reduviidae): molecular evidence of a New World origin of the Asiatic clade. Mol Phylogen Evol 2002; 23: 447-457.

21. Espínola H, Rodriguez F, Bermudez M, Tonn R. Informaciones sobre la biologia y el ciclo de vida de Triatoma maculata (Erichson, 1848) (Hemiptera, Reduviidae, Triatominae), en condiciones de laboratorio. Bol Dir Malariol 1981; 21: 140142.

22. Feliciangeli MD, Rabinovich J. Vital statistics of Triatominae (Hemiptera: Reduviidae) under laboratory conditions II. Triatoma maculata. J Med Entomol $1985 ; 22: 43-48$.

23. Luitgards-Moura JF, Vargas AB, Almeida CE, Magno-Esperança G, AgapitoSouza R, Folly-Ramos E, et al. A Triatoma maculata (Hemiptera, Reduviidae, Triatominae) population from Roraima, Amazon Region, Brazil, has some bionomic characteristics of a potential Chagas disease vector. Rev Inst Med Trop São Paulo 2006; 47: 131-137. 